\title{
APPLICATION OF LEAN TOOLS FOR IMPROVED EFFECTIVENESS IN MAINTENANCE OF TECHNICAL SYSTEMS FOR SPECIAL PURPOSES
}

\author{
ZASTOSOWANIE NARZĘDZI SZCZUPŁEGO UTRZYMANIA RUCHU \\ DO POPRAWY EFEKTYWNOŚCI OBSŁUGI SYSTEMÓW TECHNICZNYCH \\ SPECJALNEGO PRZEZNACZENIA
}

\begin{abstract}
Today, executives from the system of maintenance of technical systems for special purposes (military combat vehicles), are trying to improve their organizational processes and create competitive advantage through increasing the quality of maintenance services (increase effectiveness), reducing the total cost (increase efficiency) and reduce the maintenance cycle-time. One of the possible ways for improvements in the maintenance system is the application of lean concept of maintenance, by usage of different tools as 5S, Layout, Visual systems, Kanban and new developed "Technical system maintenance" tool. In order to gain a better understanding of this concept, the paper presents a new developed maintenance model for the application of the lean concept in the real maintenance system. The results of empirical and experimental testing of the proposed model are analysed based on Analysed of methods and effects of improvements (IMEA), Benchmarking methods and multi-criteria, 22 analysis by using the statistical software application MINITAB. The special character of experimental testing are obtained regression equations that describe the changes of the duration of the maintenance cycle, depending on the applied lean tools. The obtained results show that the duration of maintenance cycle is reduced for about $23 \%$, the improvement of maintenance effectiveness is around $14 \%$ and the efficiency is showing an upward trend.
\end{abstract}

Keywords: effectiveness, efficiency, lean tools, maintenance, readiness, technical system.

\begin{abstract}
W dzisiejszych czasach, kadra kierownicza zarządzająca systemami utrzymania ruchu układów technicznych specjalnego przeznaczenia (np. wojskowych pojazdów bojowych) stara się usprawniać procesy organizacyjne i tworzyć przewagę konkurencyjna poprzez podniesienie jakości usług serwisowych (zwiększenie efektywności), redukcję kosztów całkowitych (zwiększenie wydajności) oraz skrócenie czasu trwania cyklu eksploatacyjnego. Jednym z możliwych sposobów udoskonalenia systemu utrzymania ruchu jest zastosowanie pojęcia szczupłego utrzymania ruchu z wykorzystaniem różnych narzędzi, takich jak 5S, Layout, Visual systems, kanban oraz nowo opracowanego narzędzia "Obshugi Ruchu Systemu Technicznego". Aby lepiej zrozumieć tę koncepcję, w artykule przedstawiono nowo opracowany model obstugi technicznej, który pozwala na zastosowanie koncepcji szczuptego utrzymania ruchu w rzeczywistym systemie obshugi. Wyniki empirycznych i eksperymentalnych badań proponowanego modelu analizowano na podstawie analizy metod i efektów doskonalenia IMEA, metod benchmarkingowych oraz analizy wielokryterialnej 22 przy użyciu oprogramowania statystycznego MINITAB. W badaniach eksperymentalnych otrzymano równania regresji, które opisuja zmiany czasu trwania cyklu eksploatacyjnego w zależności od zastosowanych narzędzi. Uzyskane wyniki wskazuja, że przy zastosowaniu proponowanej metody czas trwania cyklu eksploatacyjnego ulega skróceniu o około 23\%, efektywność utrzymania ruchu wzrasta o około 14\%, a wydajność wykazuje tendencję wzrostowa.
\end{abstract}

Stowa kluczowe: efektywność, wydajność, narzędzia szczuptego utrzymania ruchu, utrzymanie ruchu, gotowość, system techniczny.

\section{Introduction}

Today there are a lot of uncertainties in the maintenance management systems which are based on implementing the principles of those traditional maintenance concepts and which generate constant losses during the maintenance process [12]. Existing manuals and other documentation for the maintenance is "poor" from the maintenance management \& control point of view. For this reason, the preparation of data for the maintenance information systems is very difficult, because it relies only on current information available from the technological process of maintenance. Therefore, the financial and time losses are recognized as the main problems in existing maintenance systems.
The lean concept of organizational management systems is a way of managing the production, development of products and services, which generates precisely defined and the desired product or service according customers' needs, $[5,18,21]$. The aim of the mentioned concept is to achieve the required quality of products or services by using fewer financial and other resources, whereby a synergy between the lean and "green" production or provision of services is achieved $[17,23]$. Even though the lean application is not easy [22], the possibilities of the lean approach are multiple. There are many examples of successful applications in all types of manufacturing [7], in industry and services [13]. The model of lean production system as hierarchical structure consisted of requirements, design parameter and variables of the process is presented by Housmand at. al. in [9]. 
There are many different lean strategies as in [24] and various maintenance performances measurement frameworks [15]. Although the "lean" management concept has its roots in the automotive industry, it has been successfully used in insurance and IT companies, health care, in public activities such as the civil service and education [16], aircraft maintenance and repair [3], and many industrial branches as described in [6].

The researches related to the application of lean philosophy in maintenance have been mainly based on findings that lean concept leads to the identification and elimination of activities that are harmful to the maintenance process and in same time increase the profit of the organizational systems [20]. The great application of the lean philosophy in maintenance is achieved in the airline branch [3]. Amir Mahmud Sahrabi et al. has shown the possibility of AHP method and Expert Choice as lean software tools that helps to decision makers to find out the possible cause of the failure and to determine activities to be undertaken in order to solve the problem, [19]. Ayad Yusuf et al. in their work [2], described the steps named DMAIC (Define, Measure, Analyze, Improve and Control), that should be applied in the large industrial systems during introduction of Lean Six Sigma maintenance, which would improve the quality and increase the profits. Alireza Irajpur at. al. in their work [11] provided a framework for the evaluation of the effectiveness achieved by applying the lean in maintenance system. They carried out a comparative analysis of maintenance performances based on TOPSIS method.

Military organizations represent very interesting and important field for research. Successful implementation of the lean methodology in the military organizations has been confirmed in the US Army, where savings reached tens of millions of dollars, while the overhaul time was reduced by more than $50 \%$, [1]. In conditions of the limited financial resources, and the required effectiveness in the maintenance of the weapons systems, the lean methodology is the way to reduce costs and maintenance cycle-time. Bearing in mind that reducing maintenance cycle-time the operational availability of weapons systems is greater and in the same time the operational capability of the whole military units is improved. The main problem in this research is to implement lean methodology in maintenance cycle of technical systems for special purposes (TSSP) in order to improve the effectiveness and the efficiency in maintenance process. In this research the attention is paid to the maintenance management of the military combat vehicles (armoured personal carriers and howitzer SH $122 \mathrm{~mm} \mathrm{DS1),}$ which are named TSSP.

In Serbian Armed Forces the maintenance program divides maintenance into three levels: depot level (strategic level), intermediate level (operational command level), and organizational level (tactical level). Tactical level assumes a basic maintenance activities at the battalion level and the technical maintenance at the brigade level. The technical maintenance involves repairs or the replacement of the modules and based on experience it covers about $60 \%$ percent of maintenance activities in the whole maintenance program. Therefore, the technical maintenance is very important and it is the subject of the research presented in this paper. As it is organized at the brigade level (the highest tactical unit in our case), the technical maintenance provides maintenance support for up to ten battalions equipped with above mentioned TSSP with different number of pieces.

The main aim of the presented research was to develop a maintenance model based on the lean methodology that could provide a high level of flexibility and to increase the effectiveness and efficiency of the maintenance. In accordance with the aim an original "lean" tool, software application, is developed and named „Technical systems maintenance" (TSM), for the management of the workshop' documentation, material and spare parts, and reporting of TSSP maintenance, [8] and the new maintenance management model is proposed.

The improvement is reflected in the reduction of the duration of maintenance cycle $(T c)$ [7], increasing the effectiveness (E) [7] and the efficiency $\left(\mathrm{E}_{\mathrm{f}}\right)$ [21] of TSSP maintenance at tactical level. The proposed maintenance model is based on application of adequate different lean tools, and new developed TSM toll, flexible enough and suitable for practical application and verification. It does not require additional investments in equipment, and it is oriented more to the maintenance management and less to the technology.

The performances of proposed model are numerical values that depend on the applied lean tools and regression equation. The empirical and experimental testing data are analysed by using the statistical software application MINITAB. The results obtained by proposed maintenance management model show the reducing of duration of maintenance cycle, improvement of maintenance effectiveness and upward trend of efficiency.

\section{Applied methods and tools}

During the development of the maintenance model the following methods are used: failure modes and effects analyses (FMEA), Benchmarking method and multi factor analysis $2^{\mathrm{k}}$. Failure modes and effects analyses is an adequate method for systematic process of identification and preventing the occurrence of problems in processes or in the exploitation of products before they are generated. For the purposes of verification of the developed model the base FMEA of the process is used, [14].

Benchmarking is one of a growing and modern management tool, developed in order to improve the characteristics of the organizational systems (business excellence), [25]. Benchmarking can be defined as the tendency of the organizational system (in this paper hereinafter referred to as maintenance system) to achieve higher performances, based on successful experiences. To reach business excellence, maintenance system is to take over the best experience from some other organization system. There are no universal models. Each system must find solution to get competitive advantage.

To verify the performances of the proposed lean maintenance management model, the check list is used, that is defined by Teri Vajerman and is given in detail in [25].

Factor analysis is often used in experiments which involve testing the influence of various factors (in this paper, lean tools) to the value of the observed characteristics (in this paper, $T c$ ), or for acceptance or rejection of the hypothesis of the influence of factors on the observed characteristic. There are a few special cases of the factor analysis. One of them is the analysis of $k$ factors, where each one has exactly two levels, [4]. For instance, levels could be the presence or absence of some factor, as it is the case in this research.

The simplest form of the factor analysis is the case with only two factors and each of them with two levels. Mathematical model of multi factor analysis is an integral part of the software tool MINITAB, [4].

For the experimental verification of the proposed maintenance management model the MINITAB software tool is used. As "lean" tools, " $5 \mathrm{~S}^{\mathrm{C}}$, „Layout" of equipment and tools (LO), visual system (VS), TSM and "Kanban" (KAN) are applied.

\section{Description of mentioned tools:}

$\mathbf{5 S}$ - The objective of this tool is to perform adequate workplace of each labor with the aim to maximize an efficiency, and to accelerate the work of the labors. The unnecessary movements of labors are eliminated by setting tools and equipment at the appropriate position, clearly visible, clean and at any moment ready for usage. A TSSP is to be complete and prepared for the maintenance in every point of view.

Layout - The goal of this tool is the drive to eliminate of movements of labor, technical system etc. that do not contribute to the making of a new value. Therefore, it is suitable to perform " $U$ " form of workplace organization where the mechanic is in the middle and everything is around its hands, [13]. 
Visual Systems - Represents the continued application of procedures in the execution of maintenance activities, safe usage and maintenance of equipment, mandatory usage of the necessary protective equipment as well as the safety signs for the tools, materials, pathways of the employees, etc. [13].

Kanban - is some kind of card for monitoring storage of spares and supplies for the TSSP maintenance, [13,20].

TSM - a newly developed "lean" tool, software application created in MS Office Access for the management of the workshop documentation, material and spare parts, and reporting of TSSP maintenance. The TSM represents a unique lean tool that is developed as a small, but very important segment of the maintenance information system. The TSM includes the data collection and activities monitoring from the reception of TSSP in workshop until the end of the maintenance, and drafting of the reports on the maintenance activities. The TSM as a lean tool is adapted to technical level of maintenance and details are given in [8]. It is similar to the lean tool, which is often used in the manufacturing organization systems called Computerized maintenance management system (CMMS). As the The Plant Maintenance Resource Center, [10], published the SAP, Maximo, MP2, i MIMS are the most often used software applications in practice. The all of those applications are defined and built for commercial usage but not suitable for maintenance systems in the military organizations. Mentioned CMMS usually defined the ordering parameters as: spares delivering address, fee instructions, supplier selection, spares selection with the defined amount, which is not sufficient for high-quality maintenance management in military organizations.

Conditions that have great impact on the maintenance management in the military organizational systems are: unscheduled requests for maintenance, hostile conditions of TSSP usage, required reliability and readiness of TSSP, unique spare parts supply system within the maintenance system, strict control of the pare part inventory conditions and strict defined maintenance activities. For the successful maintenance management under these circumstances, it is necessary to have the appropriate information available to the authorities at all levels of maintenance system. This ensures centralized maintenance management, unified purchasing and payment services at a certain level of organization, spares inventory management and their rational use, monitoring of the uniform norms and the maintenance documentation, maintenance resource management, creation of the conditions for the analysis of TSSP reliability and as well as reducing the maintenance cycle-time.

The TSM is application developed in Microsoft Access 2003 software package. It consists of a database, in which are stored all the data necessary for the application operation, and lines of interconnections between the user and the database. The logical link tables of the TSM, as a hurt of developed application, is shown in figure 1 .

The database is realized of interrelated tables:

tblTS - the identification and the codification numbers of TSSP,

tblTS1 - contains data related to a specific TSSP (registration number, chassis and engine number, the code of tactical units),

tblTI - a type of the corrective and the preventive maintenance with the description of the technological activates and their estimated duration $(\mathrm{TH})$,

tblSparepart - provides information about the stocks of the spare parts and the consumables in storage and their minimum and maximum amount (necessary for the preparation of requisitions),
tblWorkshopSheet- provides data for the inventory records (workshop operations lists): the number and the date of the first record, required completion date, work hours achieved by the specific specialty, and the name of the person who has received (delivered) the item,

tblNecessarySpareparts - a necessary spares list (with codification number) for the maintenance activity for the particular item,

tblMaintenance - provides information about the type of the maintenance for the specific item.

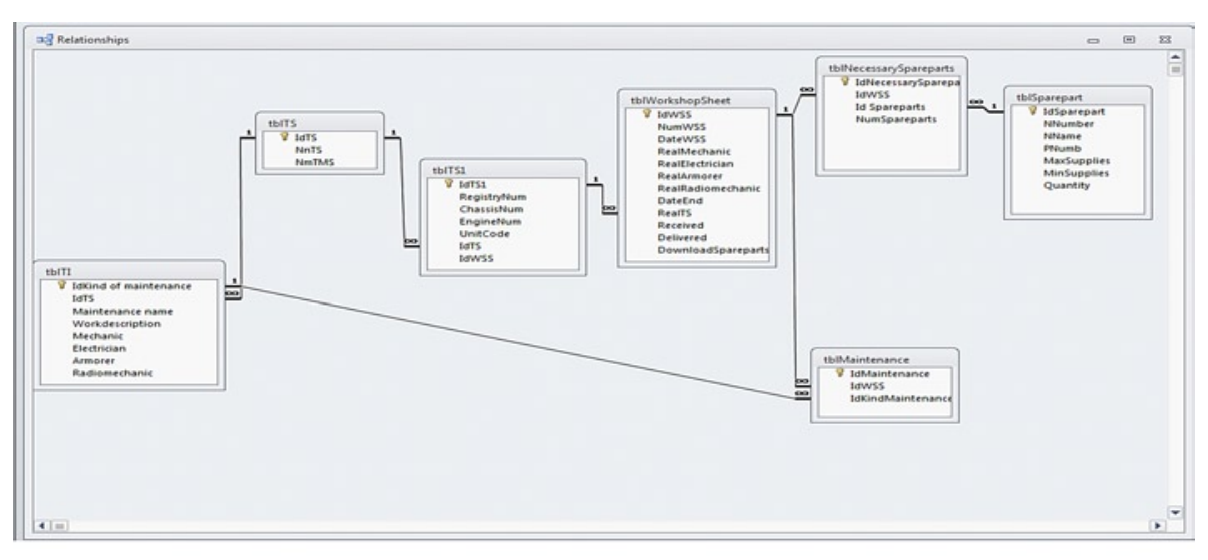

Fig. 1. Logical link of tables within the TSM

Developed TSM application provides the more flexible approach to the TSSP maintenance management than already known CMMS that have not found a direct application in the TSSP maintenance management. A more flexible approach to maintenance management of TSSP, that provides TSM, is possible because the logical data connection in the database is already known. In addition, the TSM is easy for usage and requires a standard MS Office software package, which is another important advantage compared to the other CMMS applications and do not require additional permissions for usage.

\section{The proposed maintenance management model}

The existing concept of TSSP maintenance is focused on maintenance technology and maintenance staff at all levels within all prescribed forms of maintenance, and less on the optimal organization of resources and the changing demands of users. In situations of a higher risk and uncertainty, it makes the maintenance system inflexible, which reduces readiness of the TSSP. Based on this reasons here is the proposed maintenance model based on the "lean" methodology.

The characteristics of the proposed TSSP maintenance management model are:

- the repair process is initiated at the request of the user or based on data of usage TSSP,

- it is a predictive maintenance model, because of the lean towards maximum maintenance capacity utilization,

- the model monitors the human potential, from the request to the end of the repair process.

In the proposed model, firstly, the analysis of the impact of certain "lean" tools is conducted, which in a relatively short period of time, could lead to reducing the repair time, improvement of effectiveness and efficiency of the TSSP maintenance system.

Components of this proposed model are the following subsystems: capacity planning, workshop scheduling, maintenance processes control and reporting.

The algorithm of planning and management process based on the lean methodology is shown in figure 2 .

In case that, in analyzing the current state of the maintenance system, the other lean tools are required, it is possible to extend group 


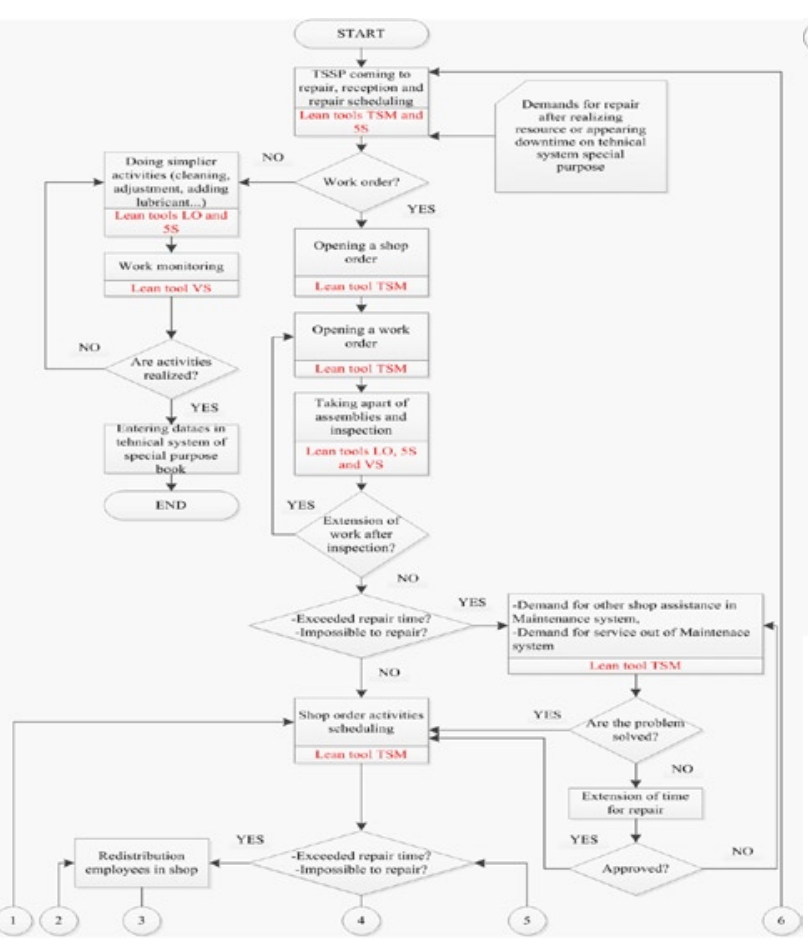

Table 1. Maintenance cycle-times after the lean application for TSSP1
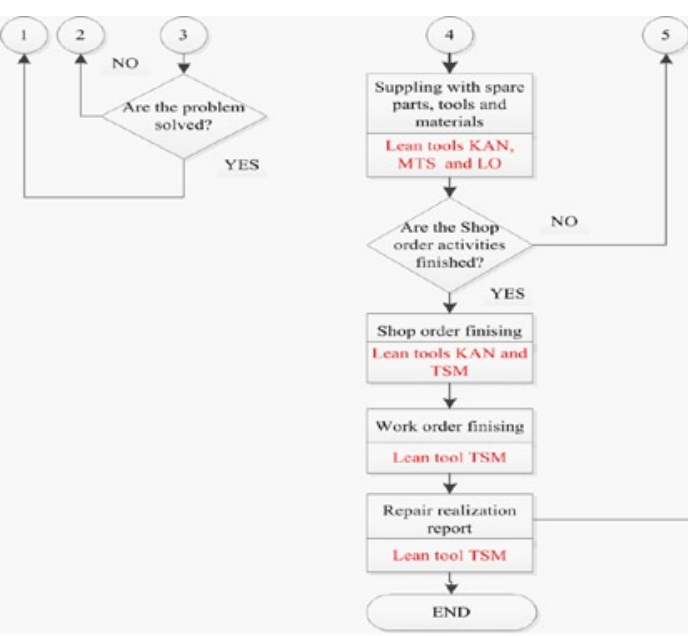

Fig. 2. The algorithm of proposed maintenance management model based on lean methodology

of obligatory lean tools. Managing the process of TSSP repair, in the proposed model, which is the subject of this paper, is made using the workshop planning documents, workshop list, working lists and lists of issuing spares and supplies.

By applying the proposed model the leadership that manages the maintenance can monitor the data that are constantly changing: capac-

\begin{tabular}{|c|c|c|c|c|c|}
\hline \multirow[t]{2}{*}{ Maintenance cycle } & \multirow[t]{2}{*}{ Activity } & \multirow[t]{2}{*}{ Responsibility } & \multirow{2}{*}{$\begin{array}{c}\text { Average maint. } \\
\text { cycle-time before } \\
\text { lean } \\
\text { (in hours) }\end{array}$} & \multicolumn{2}{|c|}{$\begin{array}{l}\text { Average maint. } \\
\text { cycle-time } \\
\text { after lean } \\
\text { (in hours) }\end{array}$} \\
\hline & & & & tool & duration \\
\hline \multirow{4}{*}{$\begin{array}{l}\text { Shipping and } \\
\text { processing }\end{array}$} & Washing and cleaning & User & 1.5 & $\begin{array}{l}5 \mathrm{~S} \\
\mathrm{VS}\end{array}$ & 0.00 \\
\hline & Item documents control & User & 0.33 & TSM & 0.10 \\
\hline & Shipping a TSSP in workshop & User & 0.5 & & 0.5 \\
\hline & $\begin{array}{l}\text { Opening of the workshop documentation and } \\
\text { handing over assets }\end{array}$ & $\begin{array}{c}\text { User / } \\
\text { Workshop manger }\end{array}$ & 0.5 & TSM & 0.1 \\
\hline \multirow{12}{*}{ repair } & TSSP visual inspection & Mechanic & \multirow{12}{*}{17.9} & \multirow{12}{*}{$\begin{array}{l}5 S \\
\text { VS } \\
\text { LO }\end{array}$} & \multirow{12}{*}{16.00} \\
\hline & TSSP dismantling & Mechanic & & & \\
\hline & Assemblies cleaning & Mechanic & & & \\
\hline & Assemblies checking and testing & Mechanic & & & \\
\hline & Assemblies dismantling & Mechanic & & & \\
\hline & Parts ordering and receiving & Mechanic & & & \\
\hline & Assemblies repairing & Mechanic & & & \\
\hline & Assembling & Mechanic & & & \\
\hline & Testing of Assemblies & Mechanic & & & \\
\hline & Mounting & Mechanic & & & \\
\hline & Testing of TSSP & Mechanic & & & \\
\hline & Data records and item delivering & Mechanic & & & \\
\hline \multirow{2}{*}{ Parts delivering } & Parts ordering & Workshop manger & 0.67 & $\begin{array}{l}\text { TSM } \\
\text { KAN }\end{array}$ & 0.1 \\
\hline & Parts inventory management & $\begin{array}{l}\text { warehouse clerk/ } \\
\text { Workshop manger }\end{array}$ & 0.5 & $\begin{array}{l}\text { TSM } \\
\text { KAN }\end{array}$ & 0.1 \\
\hline \multirow{3}{*}{$\begin{array}{l}\text { Documentation con- } \\
\text { trol and reporting }\end{array}$} & Workshop documentation control & Workshop manger & 0.25 & TSM & 0.0 \\
\hline & Completion of the workshop documentation & Workshop manger & 0.08 & TSM & 0.0 \\
\hline & Report writing & Workshop manger & 0.17 & TSM & 0.02 \\
\hline \multicolumn{3}{|c|}{$\Sigma$} & 22.4 & & 19.92 \\
\hline
\end{tabular}


ity, performance workers... The proposed model can be considered as modern, because compared to the conventional methods applied in maintenance management, do not consider maintenance system as a priori disordered and in much of activities impossible to manage.

The greatest achievement of the proposed model is its holistic approach to the maintenance management, which is reflected in the consistent application of selected appropriate "lean" tools and principles in all functions and the activities within the maintenance cycle, in order to achieve a greater improvement compared to the previous state.

\section{Maintenance management model verification for two technical systems for special purposes}

For the verification of the proposed model the empirical and experimental testing with the results analysis is performed. Empirical and experimental verification of the TSSP maintenance management model were made in the workshop for technical (tactical level) maintenance.

Two independent technical systems for special purposes (armoured personal carrier-TSSP1 and howitzer SH $122 \mathrm{~mm}$ DS1-TSSP2) are observed for the three years. The 102 work orders for each TSSP were registered during observing time. The described lean tools are applied in a real workshop for technical maintenance for both TSSP (in a selected group of activities of technical maintenance), and the results are applied in similar activities of technical maintenance in all other work orders, using the general scientific methods of induction.

The observed characteristics of the empirical and experimental testing of the developed "lean" model are: maintenance cycle time $\left(T_{c}\right)$, effectiveness expressed by coefficient of availability $(R)$ and efficiency $\left(E_{f}\right)$, which is based on the following equations, respectively:

$$
\begin{gathered}
T_{c}=t_{p f}+t_{r e}+t_{s} \\
R=\frac{t_{u}}{t_{u}+t_{d}} \\
E_{f}=\frac{T_{r c}}{T_{p c}}
\end{gathered}
$$

where $t_{p f}$ - time for the preparation and finilyzing work, $t_{r e}$ - time for repair execution, $t_{s}$ - time for the supply with spares and expendable materials, $t_{u}$ - uptime, $t_{d}$ - downtime, $T_{r c}$ - real maintenance cycle,

\begin{tabular}{|c|c|c|c|c|c|}
\hline \multirow[t]{2}{*}{ Maintenance cycle } & \multirow[t]{2}{*}{ Activity } & \multirow[t]{2}{*}{ Responsibility } & \multirow{2}{*}{$\begin{array}{l}\text { Average maint. } \\
\text { cycle-time } \\
\text { before lean } \\
\text { (in hours) }\end{array}$} & \multicolumn{2}{|c|}{$\begin{array}{l}\text { Average maint. } \\
\text { cycle-time } \\
\text { after lean } \\
\text { (in hours) }\end{array}$} \\
\hline & & & & tool & \\
\hline \multirow{4}{*}{$\begin{array}{l}\text { Shipping and } \\
\text { processing }\end{array}$} & Washing and cleaning & User & 1.5 & $\begin{array}{l}5 \mathrm{~S} \\
\mathrm{VS}\end{array}$ & 0.00 \\
\hline & Item documents control & User & 0.33 & TSM & 0.1 \\
\hline & Shipping a TSSP in workshop & User & 0.5 & & 0.5 \\
\hline & $\begin{array}{l}\text { Opening of the workshop documentation and } \\
\text { handing over assets }\end{array}$ & $\begin{array}{c}\text { User / } \\
\text { Workshop manger }\end{array}$ & 0.5 & TSM & 0.1 \\
\hline \multirow{12}{*}{ repair } & TSSP visual inspection & Mechanic & \multirow{12}{*}{11.1} & \multirow{12}{*}{$\begin{array}{l}5 S \\
\text { VS } \\
\text { LO }\end{array}$} & \multirow{12}{*}{10.20} \\
\hline & TSSP dismantling & Mechanic & & & \\
\hline & Assemblies cleaning & Mechanic & & & \\
\hline & Assemblies checking and testing & Mechanic & & & \\
\hline & Assemblies dismantling & Mechanic & & & \\
\hline & Parts ordering and receiving & Mechanic & & & \\
\hline & Assemblies repairing & Mechanic & & & \\
\hline & Assembling & Mechanic & & & \\
\hline & Testing of Assemblies & Mechanic & & & \\
\hline & Mounting & Mechanic & & & \\
\hline & Testing of TSSP & Mechanic & & & \\
\hline & Data records and item delivering & Mechanic & & & \\
\hline \multirow{2}{*}{ Parts delivering } & Parts ordering & Workshop manger & 0.67 & $\begin{array}{l}\text { TSM } \\
\text { KAN }\end{array}$ & 0.1 \\
\hline & Parts inventory management & $\begin{array}{l}\text { warehouse clerk/ } \\
\text { Workshop manger }\end{array}$ & 0.5 & $\begin{array}{l}\text { TSM } \\
\text { KAN }\end{array}$ & 0.1 \\
\hline \multirow{3}{*}{$\begin{array}{l}\text { Documentation } \\
\text { control and report- } \\
\text { ing }\end{array}$} & Workshop documentation control & Workshop manger & 0.25 & TSM & 0.0 \\
\hline & Completion of the workshop documentation & Workshop manger & 0.08 & TSM & 0.0 \\
\hline & Report writing & Workshop manger & 0.17 & TSM & 0.02 \\
\hline \multicolumn{3}{|c|}{$\Sigma$} & 15.60 & & 11.12 \\
\hline
\end{tabular}
$T_{p c}$ - planed maintenance cycle.

Table 2. Maintenance cycle-times after the lean application for TSSP2. 
Table 3. Obtained results of the application of the proposed model

\begin{tabular}{|c|c|c|c|c|c|c|c|}
\hline \multirow[b]{2}{*}{ TSSP } & \multirow[b]{2}{*}{$\begin{array}{c}\mathrm{T}_{\mathrm{c}}(\mathrm{h}) \\
\text { before lean }\end{array}$} & \multirow[b]{2}{*}{$\begin{array}{c}\mathrm{T}_{\mathrm{c}}(\mathrm{h}) \\
\text { after lean }\end{array}$} & \multicolumn{2}{|c|}{$E_{\text {before lean }}$} & \multicolumn{2}{|c|}{$\mathrm{E}_{\text {after lean }}$} & \multirow[b]{2}{*}{$\begin{array}{l}E_{f}(\text { before lean }) \\
/ E_{f}(\text { after lean })\end{array}$} \\
\hline & & & $\begin{array}{c}\mathrm{R} \\
(0-1)\end{array}$ & $\begin{array}{l}\text { Number of points } \\
\text { before lean }\end{array}$ & $\begin{array}{c}\mathrm{R} \\
(0-1)\end{array}$ & $\begin{array}{l}\text { Number of points* } \\
\text { after lean }\end{array}$ & \\
\hline TSSP1 & 22.4 & 16.9 & 0.98 & 228 & 0.99 & 265 & \multirow{2}{*}{$\begin{array}{l}0.89 / 0.75 \text { in- } \\
\text { creased }\end{array}$} \\
\hline IMPROVEMENT & \multicolumn{2}{|c|}{ lowered 5.5 (23 \%) } & \multicolumn{4}{|c|}{ increased $14 \%$} & \\
\hline TSSP2 & 15.6 & 11.7 & 0.98 & 228 & 0.99 & 265 & \multirow{2}{*}{$\begin{array}{l}0.86 / 0.75 \\
\text { increased }\end{array}$} \\
\hline IMPROVEMENT & \multicolumn{2}{|c|}{ lowered 3.8 (24 \%) } & \multicolumn{4}{|c|}{ increased $14 \%$} & \\
\hline
\end{tabular}

*-based on benchmarking method

Table 4. Results obtained by application lean tools LO, 5S, VS, TSM and Kanban for TSSP1

\begin{tabular}{|c|c|c|c|c|}
\hline $\begin{array}{c}\text { Functions of maintenance } \\
\text { system }\end{array}$ & applied „lean“ tool & $\begin{array}{c}\mathrm{T}_{\mathrm{c}}(\mathrm{h}) \\
\text { before „lean“ } \\
\text { pre }\end{array}$ & $\begin{array}{c}\mathrm{T}_{\mathrm{c}}(\mathrm{h}) \\
\text { after „lean“ }\end{array}$ & IMPROVEMENT \\
\hline preparation of repair & „5S“, VS, TSM & 2,83 & 0,7 & lowered 2,13(75\%) \\
\hline realization of repairs & $\ldots 5 S^{\prime \prime}, \mathrm{VS}, \mathrm{L}$ & 17,9 & 16,2 & lowered $1,9(11 \%)$ \\
\hline spares supply & TSM, KAN & 1,17 & 0,02 & lowered $0,97(8 \%)$ \\
\hline finalization & TSM & 0,5 & 0,2 & lowered $0,48(96 \%)$ \\
\hline
\end{tabular}

Table 5. Results obtained by application lean tools LO, 5S, VS, TSM and Kanban for TSSP2

\begin{tabular}{|c|c|c|c|c|}
\hline $\begin{array}{l}\text { Functions of maintenance } \\
\text { system }\end{array}$ & applied „lean“ tool & $\begin{array}{c}\mathrm{T}_{\mathrm{c}}(\mathrm{h}) \\
\text { before „lean“ } \\
\text { pre }\end{array}$ & $\begin{array}{c}\mathrm{T}_{\mathrm{c}}(\mathrm{h}) \\
\text { after „lean“ } \\
\text { FF }\end{array}$ & IMPROVEMENT \\
\hline preparation of repair & „5S“, VS, TSM & 2,83 & 0,7 & lowered 2,13 (75\%) \\
\hline realization of repairs & „5S“, VS, L & 11,1 & 10,2 & lowered 0,9 (8\%) \\
\hline spares supply & TSM, KAN & 1,17 & 0,2 & lowered 0,97 (8\%) \\
\hline finalization & TSM & 0,5 & 0,02 & lowered 0,48 (96\%) \\
\hline
\end{tabular}

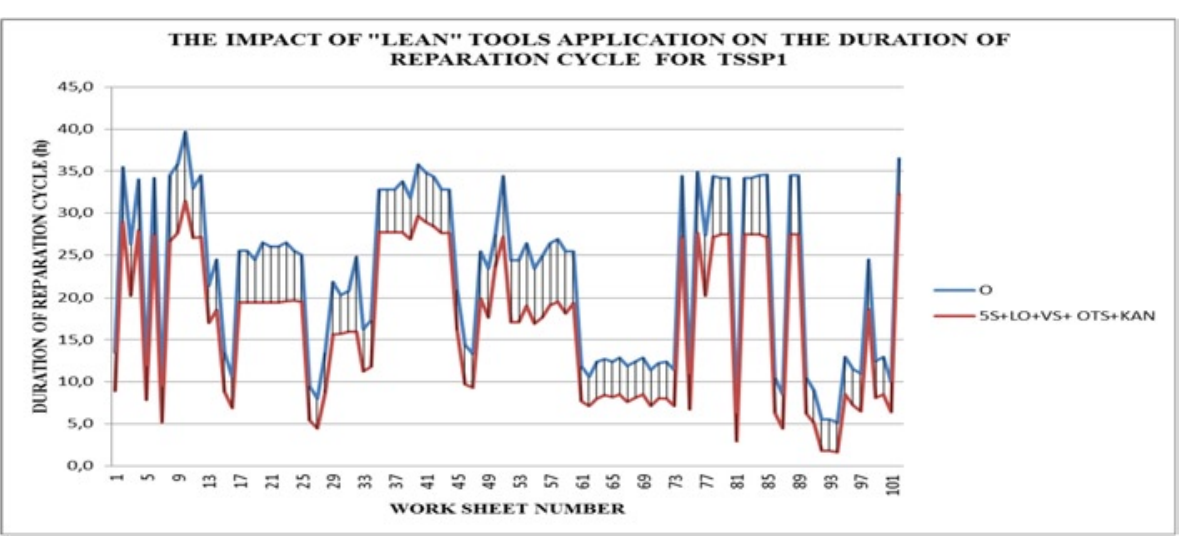

Fig. 3. The duration of technical maintenance, before (the blue line) and after (the red line) lean tools application $(L O+5 S+V S+T S M+K A N)$ for TSSP1

\subsection{The empirically obtained results}

Based on workshop documents analysis, and the measurement of the maintenance cycle-time in real maintenance system an average maintenance cycle-time $\left(t_{m c}\right)$ for the TSSN1 and the TSSN2 is de- fined. The results of the application of specific lean tools for two independent TSSP are shown in the following tables.

Reducing the $T_{r c}$ is slightly higher in the case of technical maintenance of TSSP1 compared to TSSP2 although the technical maintenance tasks take place in the same facility by the same workforce. This is due to the different content and scope of activities of technical maintenance prescribed in technical documentation.

The graphical representation of the results for TSSP1 and TSSP2 are shown in following figures.

The final results of the application of the proposed maintenance model and its improvement compared to the current situation (before lean) are shown in table 3.

Reducing the $T_{r c}$ is slightly higher in the case of technical maintenance of TSSP1 compared to TSSP2 although the technical maintenance tasks take place in the same facility by the same workforce. This is due to the different content and scope of activities of technical maintenance prescribed in technical documentation. 


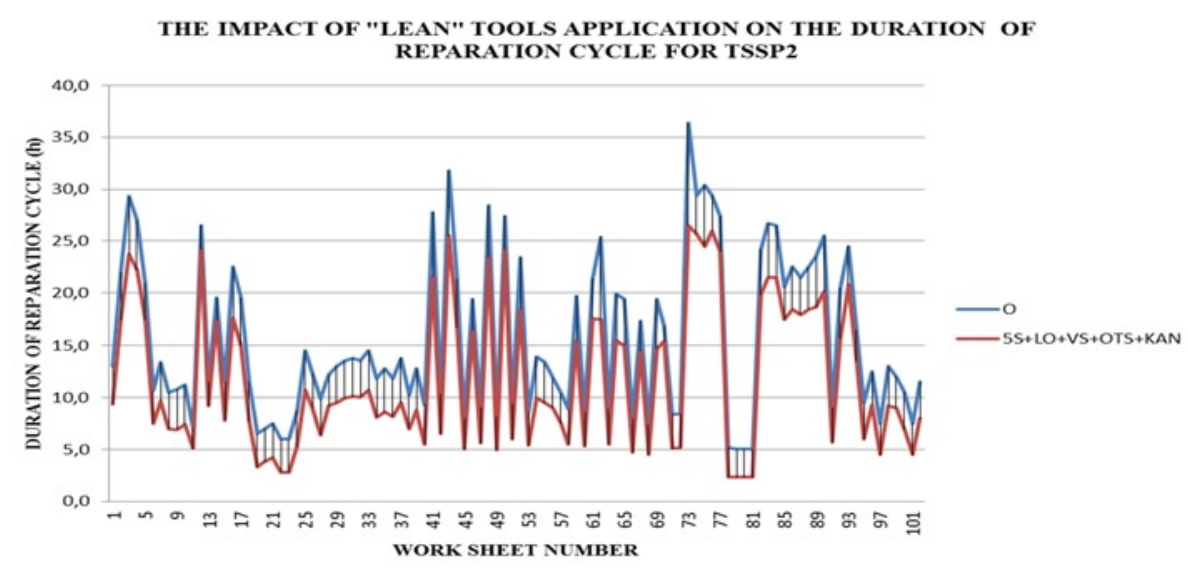

Fig. 4. The duration of technical maintenance, before (the blue line) and after (the red line) lean tools application $(L O+5 S+V S+T S M+K A N)$ for TSSP 2

Table 6. Maintenance cycle-time $T_{c}$ for TSSP1

\begin{tabular}{|c|c|c|c|c|c|}
\hline \multirow{3}{*}{$\begin{array}{l}\mathrm{T}_{\mathrm{c}} \text { for TSSP1 (armoured per- } \\
\text { sonal carrier M80) in hours }\end{array}$} & \multicolumn{5}{|c|}{ LEAN concept TSSP1 } \\
\hline & \multirow{2}{*}{$\begin{array}{l}\text { without } \\
\text { LEAN tools }\end{array}$} & \multicolumn{4}{|c|}{ with LEAN tools } \\
\hline & & $5 S$ & $5 S+V S$ & $\begin{array}{c}5 \mathrm{~S}+\mathrm{VS}+ \\
\mathrm{TSM}\end{array}$ & $\begin{array}{c}5 \mathrm{~S}+\mathrm{VS}+ \\
\mathrm{TSM}+\mathrm{KAN}\end{array}$ \\
\hline \multirow{4}{*}{ 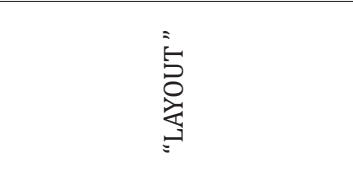 } & 23.16 & 20.07 & 18.94 & 17.69 & 17.27 \\
\hline & 22.45 & 20.05 & 18.92 & 17.67 & 17.25 \\
\hline & 22.20 & 20.00 & 18.87 & 17.62 & 17.20 \\
\hline & 21.80 & 19.74 & 18.61 & 17.36 & 16.94 \\
\hline \multirow{4}{*}{ 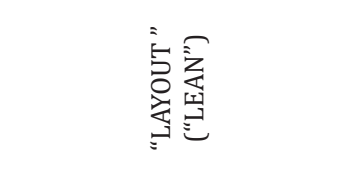 } & 21.55 & 19.85 & 18.70 & 17.47 & 17.05 \\
\hline & 21.25 & 19.70 & 18.55 & 17.32 & 16.90 \\
\hline & 21.00 & 19.50 & 18.35 & 17.12 & 16.70 \\
\hline & 20.09 & 18.70 & 17.55 & 16.32 & 15.90 \\
\hline
\end{tabular}

Table 7. Maintenance cycle-time $T_{c}$ for TSSP2

\begin{tabular}{|c|c|c|c|c|c|}
\hline \multirow{3}{*}{$\begin{array}{c}\mathrm{T}_{\mathrm{c}} \text { for TSSP2 (howitzer SH } \\
122 \text { mm DS1) } \\
\text { in hours }\end{array}$} & \multicolumn{5}{|c|}{ LEAN concept TSSP2 } \\
\hline & \multirow{2}{*}{$\begin{array}{l}\text { without } \\
\text { LEAN tools }\end{array}$} & \multicolumn{4}{|c|}{ with LEAN tools } \\
\hline & & $5 S$ & $5 S+V S$ & $\begin{array}{c}5 \mathrm{~S}+\mathrm{VS}+ \\
\text { TSM }\end{array}$ & $\begin{array}{c}5 \mathrm{~S}+\mathrm{VS}+ \\
\mathrm{TSM}+\mathrm{KAN}\end{array}$ \\
\hline \multirow{4}{*}{ 窎 } & 15.80 & 14.50 & 13.65 & 12.42 & 12.00 \\
\hline & 15.60 & 14.35 & 13.50 & 12.27 & 11.85 \\
\hline & 15.40 & 14.33 & 13.48 & 12.25 & 11.83 \\
\hline & 15.30 & 14.31 & 13.46 & 12.23 & 11.81 \\
\hline \multirow{4}{*}{ 言 } & 15.20 & 14.30 & 13.45 & 12.22 & 11.80 \\
\hline & 15.10 & 14.22 & 13.37 & 12.14 & 11.72 \\
\hline & 14.90 & 14.00 & 13.15 & 11.92 & 11.35 \\
\hline & 14.60 & 13.85 & 13.00 & 11.77 & 11.15 \\
\hline
\end{tabular}

Table 8. Regression analysis and the analysis of variance influence of factors on $T_{c}$ for TSSP1

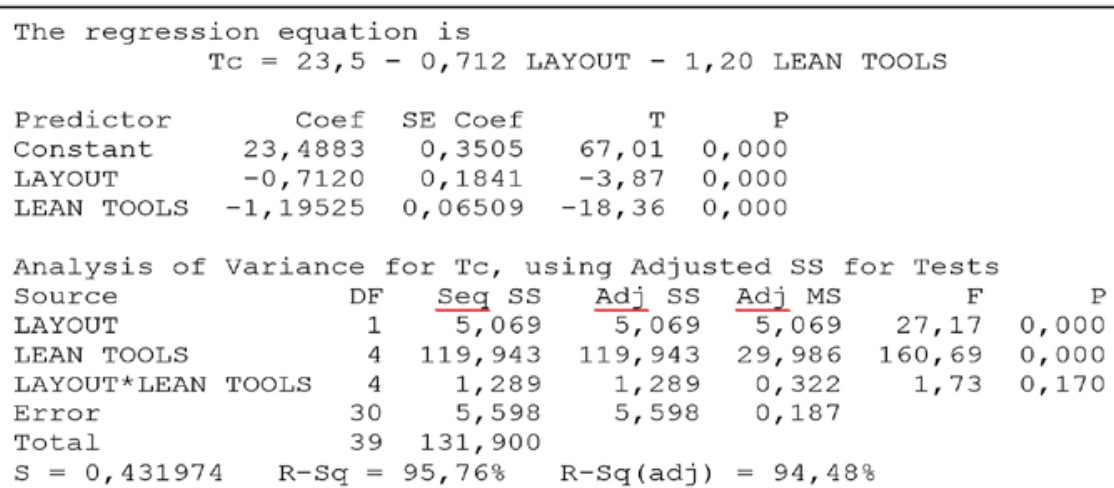

The graphical representation of the results for TSSP1 and TSSP2 are shown in following figures.

In figures 3 and 4 is shown the trend of decreasing the duration of maintenance cycle for TSSP1 and TSSP2 after lean tools application. The reduction of the maintenance cycle-time is achieved successively by $5 \mathrm{~S}$, TSM, LO, VS and KAN. The maximum effect is obtained when all five lean tools are applied at the same time.

\subsection{The experimentally obtained results}

After empirical tests of proposed model for TSSP maintenance, the 22 analysis of the impact of described lean tools is performed. The analysis of influence factors is considered in relation to the duration of the maintenance cycle time $T_{c}$, using the statistical software MINITAB.

For this experiment lean tools are grouped as:

- Factor 1: LAYOUT with two levels: 1.0 current state and 2.0 - future state

- Factor 2: group of LEAN TOOLS with the following levels: $1.0-5 \mathrm{~S} ; 2.5-5 \mathrm{~S}+\mathrm{VS} ; 4.0-$ $5 \mathrm{~S}+\mathrm{VS}+\mathrm{TSM}$; and $5.5-5 \mathrm{~S}+\mathrm{VS}+\mathrm{TSM}+\mathrm{KAN}$.

The data of duration of maintenance cycle $T_{c}$ after two factors application for the all levels and for both TSSP are given in following tables.

Tables 6 and 7 are the basis for the formation of the starting matrices for regression analysis and analysis of variance influence of factors on $T_{c}$ which is for both TSSP given in tables 8 and 9 respectively. In following tables the value " $F$ " represents a Fisher criterion of statistical significance of $T_{c}$ changes after the application of the described factors. The values of "P" represent a criterion for evaluating the impact of factors on $T_{c}$. The value of "R-Sq" represents the degree of approximation of empirical data based on linear model.

From statistically obtained result for TSSN1 (Tab. 8), it could be seen that criterion for evaluating the impact of factors on $T_{c}$, (,LAYOUT“ and „LEAN" TOOLS) is $P=0$. That means that those factors have impact on maintenance cycle-time. In a case of interaction of those factor (,LAYOUT*LEAN“ TOOLS) the value for criterion is $P=0,170$, and that means that in this case the factors do not have impact on maintenance cycle-time.

For test evaluation a statistical impact of $\alpha=0,05$ and degrees of freedom $\mathrm{k}_{2}=4$ (for LEAN TOOLOS) and $k_{1}=1$ (for „LAYOUT“), the critical value for criterion of statistical significance is $F_{c}=8,71$. Based on above represented results it is obvious that criterion of statistical significance $F$ is higher than its critical value (for factors („LAYOUT“ and „LEAN“ TOOLS) which is proved that those factors have the impact on maintenance cycle-time 
Table 9. Regression analysis and the analysis of variance influence of factors on $T_{c}$ for TSSP2

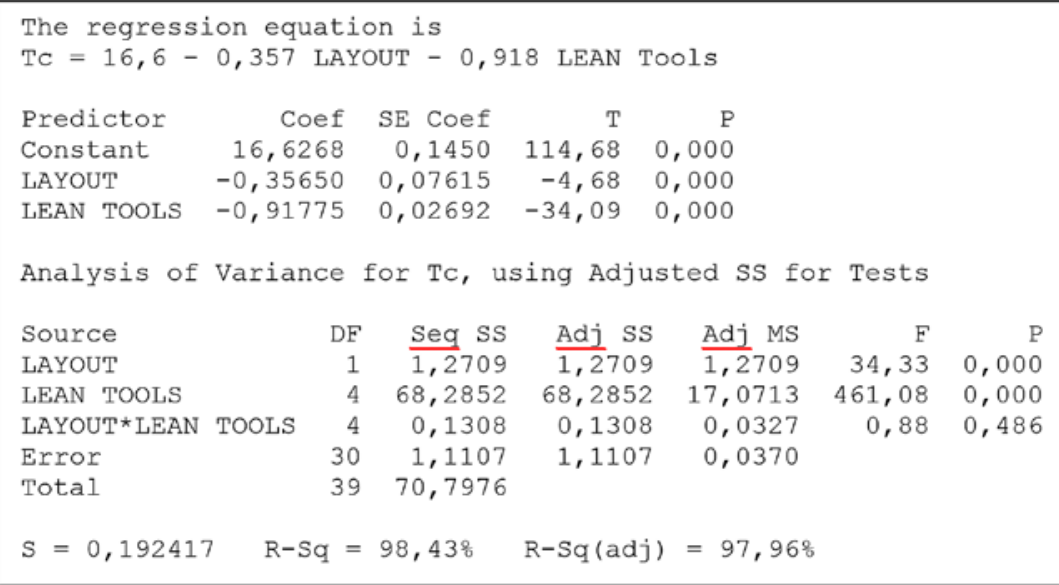

nificance $F$ is lover than its critical value which means that statistical test was correct or those factors do not have impact on maintenance cycle-time. The degree of approximation of empirical data based on linear model $\mathrm{R}-\mathrm{Sq}=95,76 \%$ shows that mathematical model, which describes statistical rule of changes of maintenance cycle-time $T_{c}$, has a high adequacy.

From statistically obtained result for TSSN2 (Tab. 9), it could be seen that criterion for evaluating the impact of factors on $T_{c}$, („LAYOUT“ and „LEAN“ TOOLS) is $P=0$, which means that those factors have impact on maintenance cycle-time. In a case of interaction of those factor („LAYOUT*LEAN" TOOLS) the value for criterion is $P=0,486$, and that means that in this case the factors do not have impact on maintenance cycle-time.

As in previous case, the criterion of statistical significance $F$ is higher than its critical value (for factors (,LAYOUT“ and „LEAN“ TOOLS) and lover than its

\section{Surface Plot of Tc vs LAYOUT; LEAN TOOLS}

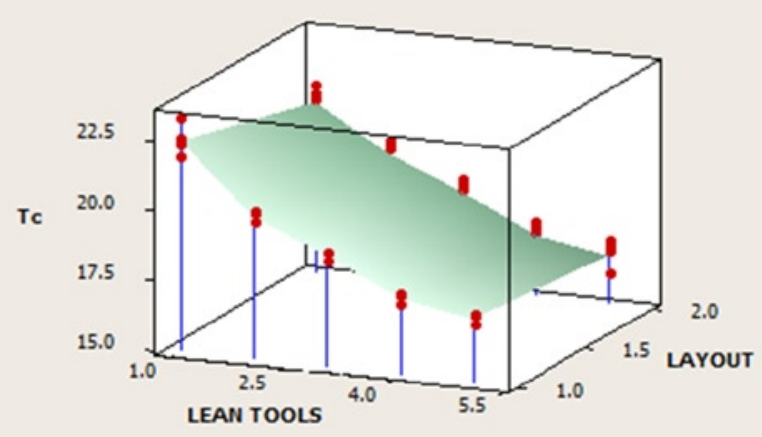

Fig. 5. Influence of LAYOUT and LEAN tools on $T_{c}$ for TSSP1

\section{Surface Plot of Tc vs LAYOUT; LEAN TOOLS}

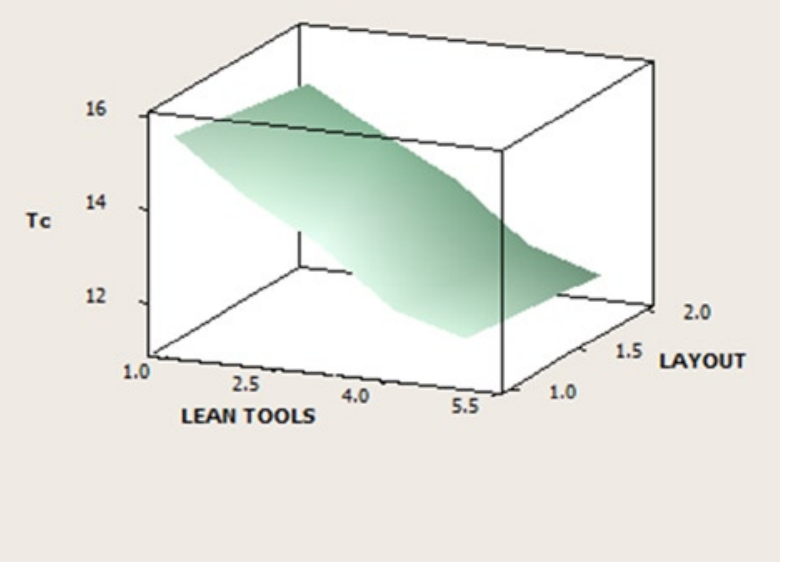

Fig. 6. Influence of LAYOUT and LEAN tools on $T_{c}$ for TSSP2

$T_{c}$. The statistical test evaluation in the case of interaction of those factors („LAYOUT*LEAN“ TOOLS) the criterion of statistical sigcritical value (for „LAYOUT*LEAN“ TOOLS) which means that statistical tests were correct.

The degree of approximation of empirical data based on linear model $\mathrm{R}-\mathrm{Sq}=98,43 \%$ shows that mathematical model, which describes statistical rule of changes of maintenance cycle-time $T_{c}$, has a high adequacy.

The data in the tables show that factors LAYOUT and LEAN TOOLS affect the change of $T_{c}$, that this influence is statistically significant, and that their interaction does not change $T_{c}$. In addition to this, the data show that the mathematical models designed for TSSP1 and TSSP2 have a high level of adequacy.

The special significance of developed model is the regression analysis, the outputs of which are equations that mathematically describe the changes of the $T_{c}$ depending on the applied lean tools (Tab. 6 and 7) and the possibility of their spatial graphics representation as it is shown in the following figures respectively. The regression equations enables to see the magnitude of impact of specific factors on maintenance cycle time $T_{c}$, that it is possible to influence them.

The graphics in figures 5 and 6 show that with every new application of "lean" tools, going from LAYOUT 1.0 to LAYOUT 2.0 the duration of $T_{c}$ is reduced. In addition, it is unambiguously confirmed that the concomitant use of described lean tools in the maintenance system led to a maximal decrease of the $T_{c}$.

\section{Conclusion}

By applying the proposed TSM and maintenance model for the technical maintenance of TSSP it is possible to track maintenance processes and the realization of workshop and work sheets, to have control under the inventories of spares and supplies, and to automatically generate requests for procurement when resources fall below the defined minimal amount.

The presented solution also enables the obtaining reports on performed maintenance activities per individual TSSP, spent spares and supplies, the required procurements of them and the achieved efficiency for the selected period of time. The research described in this paper has special value because of the fact that the experiment was conducted in a real workshop for the technical maintenance of TSSP, after which the results of research are confirmed based on statistical analysis.

The obtained results show that it is possible to develop and implement the lean concept and tools in each function of the maintenance cycle the influence of which is reflected in the reduction of maintenance cycle-time, which is around $23 \%$, depending on the applied function. The improvement of the maintenance effectiveness is around $14 \%$. 
Implementation of research, in real terms, contributed to changing the mindset of management and employees in real workshop for technical maintenance, in the direction of accepting the change in a positive way. The present lean model for technical maintenance of
TSSP is a good basis for further research into the possibility of applying lean principles, methods and tools in all levels of maintenance, not only on technical maintenance.

\section{References}

1. Apte U, Kang K. Lean six sigma for reduced cycle costs and improved readiness. Acquisition Research Sponsored Report Series, Naval Postgraduate School, Monerey, California, 2006.

2. Ayadi Y, Chaib R, Verzea I. Contribution to the optimization of strategy of maintenance by lean six sigma. Physics procedia 2014; 55(2014): 512-518.

3. Ayeni P, Baines T, Lightfoot H, Ball P. State of the art of "Lean" in the aviation maintenance repair overhaul industry. Journal of Engineering Manufacture 2011; 225(11): 2108-2123, https://doi.org/10.1177/0954405411407122.

4. Basilevsky A T. Statistical factor analysis and related methods: theory and applications, Vol. 418. John Wiley \& Sons, 2009.

5. Bhasin S, Burcher P. Lean viewed as a philosophy. Journal of Manufacturing Technology Management 2006; 17(1): 56-72, https://doi. org/10.1108/17410380610639506.

6. Biswas S, Chowdhury B. Industrial Applications and Practices of Six Sigma - A Literature Review. International Advanced Research Journal in Science, Engineering and Technology 2016; 3(3): 176-179, https://doi.org/10.17148/IARJSET.2016.3337

7. Božičković R, Radošević M, Ćosić I, Soković M, Rikalović A. Integration of simulation and lean tools in effective production systems - case study. Journal of Mechanical Engineering 2012; 58 (11): 642-652, https://doi.org/10.5545/sv-jme.2012.387.

8. Epler I. "Lean" concep of special purpose technical system maintenance. PhD thesis, University of East Sarajevo, East New Sarajevo, 2016. (In serbian)

9. Houshmand M, Jamshidnezhad B. An extended model of design process of lean production systems by means of process variables. Robotics and Computer: Integrated Manufacturing 2006; 22(1): 1-16, https://doi.org/10.1016/j.rcim.2005.01.004.

10. http://www.plant-maintenance.com/articles/CMMS_survey_2004.shtml

11. Irajpour A, Fallahian-Najafabadi A, Ali Mahbod M, Karimi M. A framework to determine the effectiveness of maintenance strategies lean thinking approach. Mathematical Problems in Engineering 2014, https://doi.org/10.1155/2014/132140

12. Legutko S. Development trends in machines operation maintenance. Eksploatacja i Niezawodnosc-Maintenance and Reliability $2009 ; 2$ : 8-16.

13. Marić B, Božičković R, Jašarević S. Softver tool for project management as support to lean concept in the process of technical systems overhaul. Proceedings 18th International Research Expert Conference "Trends in the Development of Machinery and Associated Technology", TMT 2014, Budapest, 2014; 177-180.

14. McDermott R E, Mikulak R J, Beauregard M R. The Basics of FMEA. New York: Productivity Press, 2009.

15. Muchiri P, Pintelon L, Gelders L, Martin H. Development of maintenance function performance measurement framework and indicators. International Journal of Production Economics 2011; 131(1): 295-302, https://doi.org/10.1016/j.ijpe.2010.04.039.

16. Nadeau S. Lean, Six Sigma and Lean Six Sigma in Higher Education: A Review of Experiences around the World. American Journal of Industrial and Business Management, 2017; 7: 591-603, https://doi.org/10.4236/ajibm.2017.75044.

17. Nash M, Poling S R, Ward S. Using Lean for faster Six Sigma results: A synchronized approach. Florida: CRC Press, 2006.

18. Shah R, Ward P T. Lean manufacturing: context, practice bundles, and performance. Journal of Operations Management 2003; 21(2): 129-149, https://doi.org/10.1016/S0272-6963(02)00108-0.

19. Shahrabi M, Shojaie A. Application of FMEA and AHP in lean maintenance. International Journal of Modern Engineering Sciences 2014; 3(1): 61-73.

20. Smith R, Hawkins B. Reduce costs, improve quality and increase market share. Oxford: Elsevier Butterworth-Heinemann, 2004.

21. Štefanić N, Gjeldim N, Mikac T. Lean concept application in production business. Tehnical Gazette 2010; 17 (3): $353-356$.

22. Thangarajoo Y, Smith A. Lean Thinking: An Overview. Industrial Engineering \& Management 2015; 4(2), https://doi.org/10.4172/21690316.1000159.

23. Veza I, Mladineo M, Gjeldum N. Selection of basic lean tools for development of croatian model of innovative smart enterprise. Tehnički vjesnik 2016; 23(5): 1317-1324.

24. Vinodh S, Chintha S K. Leanness assessment using multigrade fuzzy approach. International Journal of Production 2011; 49(2): 431-445, https://doi.org/10.1080/00207540903471494.

25. Wireman T. Benchmarking BEST practices in maintenance management. New York: Industrial Press, 2004.

\section{Igor EPLER \\ Vlada SOKOLOVIĆ \\ Marjan MILENKOV \\ Milan BUKVIĆ}

Military Academy, University of Defense in Belgrade

Generala Pavla Jurišića Šturma str.No. 33, 11000 Belgrade, Serbia

E-mails: igor.epler@va.mod.gov.rs, vlada.sokolovic@va.mod.gov.rs, marjan.milenkov@va.mod.gov.rs,milan.bukvic@vs.rs 